\section{Economising subsidies for green housing features: A stated preference approach}

In light of the enormous amounts of energy and resources consumed by housing development and operations, many governments have started recognising the urgent need to promote green or eco-friendly housing with the aim of achieving sustainable development. Apart from regulations, governments can offer incentives to developers to provide green features in their developments by offering subsidies in various forms. However, such subsidisation is often uneconomical. In theory, market forces can lead to green housing provision without any government intervention if the market players are willing to pay extra for the green features of housing. Against this background, this article presents the findings of a study that compared potential homebuyers' willingness to pay (WTP) for various green housing features based on findings from a structured questionnaire survey in Macau. The housing attributes under investigation included uses of green materials (e.g., sustainable forest products) and construction methods (e.g., prefabrication), energy-efficient technologies (e.g., LED lighting) and water-saving devices (e.g., grey-water recycling systems). Results indicate that the respondents' WTP was mainly motivated by economic incentives. Green housing attributes that can offer direct financial benefits corresponded to greater WTP. The policy implications of the research findings then follow.

Key words: environmental economics, green construction, green consumerism, sustainability, willingness to pay 


\section{Introduction}

The role of real estate or construction in mitigating climate change is becoming increasingly prominent because building construction and operations consume a very large proportion of energy (Suzuki et al., 1995; Swan \& Ugursal, 2009). For example, the construction sector consumes about $40 \%$ of China's aggregate end-use energy, taking the production of construction materials and the entire building life cycle into account (Chinese Academy of Social Sciences, 2013). In light of the significant amount of carbon emissions coming from this sector, the residential construction industry has faced a paradigm change. Green, eco-friendly or sustainable construction has become a new orthodoxy in architecture and building engineering. Although many researchers, such as Mark Bhatti (1996) and Vida Maliene and Naglis Malys (2009), suggest that the residential construction industry has an environmental responsibility to make the built environment greener, drivers such as altruism, norms or environmental citizenship are not strong enough for the production of sustainable buildings. From the perspective of real estate developers, the major barrier to the supply of green buildings is the seemingly higher construction costs of green buildings (Casals, 2006).

Given that the production of green buildings is not automatic, governments may need to formulate instruments to promote green construction. Figure 1 shows a hierarchy of green construction policy. The bottom level is the employment of a mandatory or "command-and-control" approach that is commonly executed through building control systems in which building designs or proposals will not be approved because of non-fulfilment of requirements for energy efficiency (Casals, 2006). For instance, it has been compulsory for all new houses in Australia to acquire a minimum acceptable house energy rating since 2003 (Australian Building Codes Board, 2006). Although this approach is usually thought to be effective in promoting green buildings because legislation can ensure code compliance, it may create market inefficiency and rent-seeking problems (Moran, 1995; Millimet et al., 2009). In addition, many resources are needed for enforcement to achieve greater compliance with regulations (Karp \& Gaulding, 1995).

The second level is subsidies for construction of green buildings. Government subsidies can come in various forms such as grants, tax relief, and bonus plot ratios (or floor space ratios). In Hong Kong, for example, bonus plot ratios are given to a site if the developer provides green features in the proposed development for the site. Nonetheless, the use of subsidies may increase the financial burden on the government. In addition, subsidies sometimes do not have public support. The Hong Kong government has been criticised for offering too many incentives for private developers to provide "green building

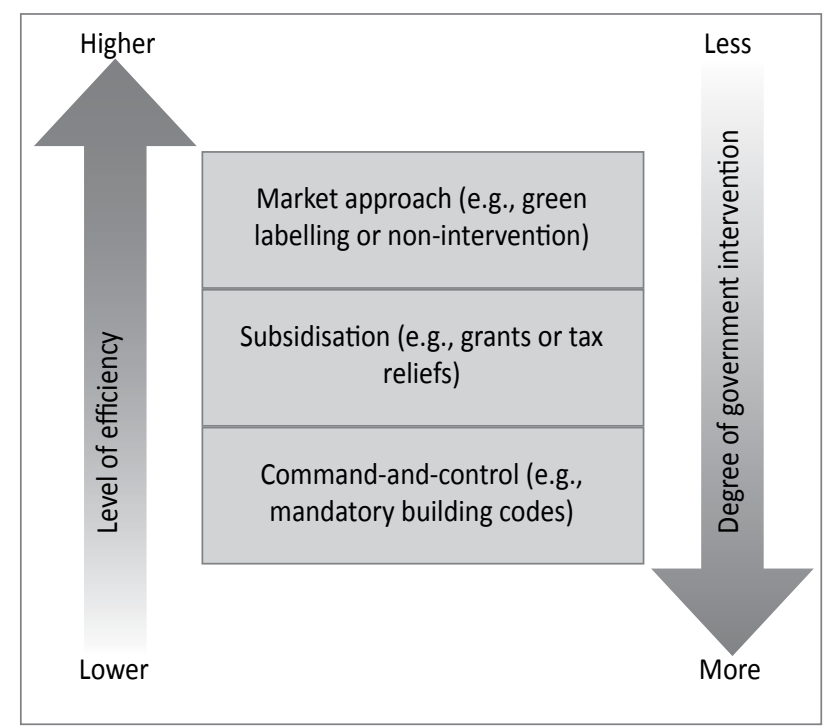

Figure 1: Hierarchy of green construction policy (illustration:Yung Yau).

features" in their new developments (Council for Sustainable Development, 2009; Ming Pao, 2009; South China Morning Post, 2009, 2010). On the other hand, the market approach, which has been considered an alternative to the legislative approach and subsidisation in tackling environmental problems, occupies the top level of the hierarchy. This approach relies on market forces that mobilise developers to provide eco-friendly housing. It works when green buildings are perceived to be of value to the end users or owners of the properties so that purchasers are willing to pay for greener properties. The role of governments is minimal at this level, and governments can adopt a non-intervention approach. Alternatively, marketbased policy instruments such as green housing labelling or benchmarking can be devised to promote pro-environmental behaviour through price signals or economic incentives.

Although the market approach is more efficient in encouraging development of green housing from the economic perspective, its operation is effective only if the voluntary provision of green housing financially benefits market players. For example, consumers in the housing market are willing to pay more for green housing so the price premiums can cover the higher costs of green housing production. However, not all homebuyers are willing to pay for greenness in the built environment. Moreover, willingness to pay (WTP) may vary across different green or environmental characteristics of housing. In this sense, it is interesting to know homebuyers' WTP for various green construction attributes.

Against this background, a study was conducted to explore the WTP of potential homebuyers in Macau for various green housing attributes based on the findings from a structured questionnaire. We presumed that WTP would vary across different types of green attributes. Macau was a good laboratory for this kind of study because the supply of green buildings in 
the city still relies on the housing market itself. There was no government intervention with respect to green construction promotion in Macau when this article was written. If the Macau government plans to move towards the goal of sustainable housing development through non-mandatory approaches in the future, it has to decide what kinds of green housing attributes should be subsidised and what kinds of attributes should be left to the market.

\section{Green housing provision: An economic perspective \\ 2.1 Costs of building green}

It is a common belief that special devices, materials or technology have to be employed to make a building greener. The costs of green buildings are thus thought to be higher (Ding, 2006; Kats et al., 2003). Ed Bartlett and Nigel Howard (2000) reported that the construction costs of more energy-efficient and eco-friendly buildings were estimated to be 5 to $15 \%$ more than those of conventional ones by quantity surveyors in the UK. Lisa Fay Matthiessen and Peter Morris (2004) determined that the development cost of a building would be 7.6 to $10.3 \%$ higher if a platinum grade in the Leadership in Energy and Environmental Design (LEED) was targeted. The cost premium dropped with the environmental target (i.e., targeting a gold or silver LEED grade). Similarly, the company CB Richard Ellis (2009) suggested that an additional $12.5 \%$ of the total cost would be needed for developing a zero-carbon building. Construction professionals and investors in Italy also perceive green buildings to be more costly to construct (Morri \& Soffietti, 2013).

Nevertheless, Greg Kats, Leon Alevantis, Adam Berman, Evan Mills and Jeff Perlman (2003) held a different view after comparing the development costs of thirty-three green buildings with those of conventionally designed ones. They found that the average rise in cost for greener buildings was slightly less than $2 \%$ of the total cost of construction, which was substantially lower than the level commonly perceived in other studies. This negligibly small cost increment can be attributed to the fact that less plant and equipment is required to serve more environmentally friendly construction (Bartlett \& Howard, 2000). This means that fewer resources are needed for the construction of a green building, which counters the increase in the cost of green construction. However, as indicated by Kats et al. (2003), non-transparency in sharing construction cost information often results in the common misperception that green buildings cost more. In fact, on account of advancement in technology and the popularity of green buildings, the costs of green developments should be declining as a result of greater experience in green construction and economies of scale.

\subsection{Returns from building green}

The mistaken belief in the high costs of green buildings calls for government intervention in the housing market. Inherent in the command-and-control and subsidisation approach is the assumption that market players (e.g., developers) are unwilling to produce green buildings voluntarily and thus have to be compelled or persuaded to do so (May, 2004). However, the evidence on returns from the incorporation of greenness or sustainability into building design is growing. As far as the residents are concerned, greener buildings offer a healthier environment to them and thus preserve or even increase their productivity (Bartlett \& Howard, 2000; Kats et al., 2003; Robinson, 2005). Kats et al. (2003) found significant productivity gains from residing in LEED-certified buildings in the U.S. The productivity gains - coming in the form of lower absenteeism, fewer headaches at work, greater retail sales and so on - were estimated between USD 36.89 and 55.33 per square foot (between USD 397.08 and 595.56 per square metre) per year. Apart from enhanced productivity, a more direct benefit that green buildings offer their residents is savings in energy consumption (Robinson, 2005).

Other than added values to residents, green buildings also offer benefits to owners and investors. The occupancy rate of a building increases with its environmental performance (Fuerst \& McAllister, 2010). In addition, many studies (Fuerst \& McAllister, 2008a, 2008b, 2011; Eichholtz, Kok \& Quigley, 2009, 2013; Cajias \& Piazolo, 2013; Högberg, 2013; Hyland, Lyons \& Lyons, 2013) showed that buildings with higher energy efficiency commanded price or rent premiums. For example, a study (Miller et al., 2008) of Energy Star and LEED-certified office buildings in the U.S. showed that on average the Energy Star and LEED certifications increased the selling prices of the buildings by $5.76 \%$ and $9.94 \%$, respectively. A study of the German housing market (Cajias \& Piazolo, 2013) found that a $1 \%$ improvement in energy conservation boosted property rents by $0.08 \%$ and prices by $0.45 \%$. From the perspective of real estate investment, Piet Eichholtz, Nils Kok and Erkan Yonder (2012) studied how the proportion of green properties in a real estate investment trust's portfolio affected the operating and stock performance in the U.S. As suggested by their findings, trusts with a higher share of green properties generally perform better, in terms of return on assets and return on equity ratios. Moreover, investing in green buildings can allow institutional investors to fulfil their corporate social responsibilities (Lorenz \& Lützkendorf, 2008).

\subsection{Willingness to pay for green products}

Empirical evidence showing that greener or more energy-efficient buildings command higher values or rents are plentiful, 
but previous studies took buildings or portfolio of properties as the investigation units. Research on market players' preferences for different types of green construction attributes or features is still very limited. At the same time, most previous studies adapted revealed-preference methods such as hedonic price modelling to the relationship between building greenness and property price or rent. However, revealed-preference methods have limitations (Boyle, 2003). For instance, revealedpreference methods do not allow the estimation of non-use value. Another limitation is the inability to estimate values for levels of quality that have not been experienced. In this regard, stated-preference approaches, particularly WTP estimation, are more commonly used in green economics or green consumerism.

Consumers' WTP for various green or eco-friendly products such as eco-labelled food, green electricity and environmentally certified wood products have been widely researched (Blend \& van Ravenswaay, 1999; Viosky et al., 1999; Roe et al., 2001; Krystallis \& Chryssohoidis, 2005). The literature indicates that consumers' WTP for greenness varies across different kinds of products. For example, green electricity from solar power generally attracts higher WTP compared to that from biomass or farm methane (Borchers et al., 2007). Soon Hee Joung, Sun Wook Park and Yoon Jin Ko (2014) showed that consumers in South Korea were willing to pay a premium for eco-friendly cosmetics, but WTP depends very much on product types. A premium of $27.7 \%$ was measured for low-priced skin care cosmetics, $21.0 \%$ for low-priced makeup cosmetics, $18.3 \%$ for high-priced skin care cosmetics and $15.3 \%$ for high-priced makeup cosmetics. On the other hand, individual buyers in the U.S. are willing to pay a $1 \%$ premium only for "greener" consumer electronic devices (Saphores et al., 2007).

In real estate, many different studies (e.g., Banfi et al., 2008; Kwak et al., 2010) have examined how much money market players are willing to pay for incorporating green or sustainable measures into properties. Research has shown that lessees were prepared to pay 5 to $10 \%$ higher rent for improved comfort and control of the environment (Maguire \& Robinson, 2000). WTP for a standard insulation window compared to an old window was estimated at $13 \%$ in Switzerland (Banfi et al., 2008).

\section{Research design}

It was not the aim of the study described in this article to determine whether consumers' WTP for a particular green housing feature could cover its cost of production because reliable construction cost data have not been easily obtainable. Instead of estimating the amount of WTP that could be expressed in monetary terms or in some other way, the study aimed to compare the WTP of potential homebuyers for vari-

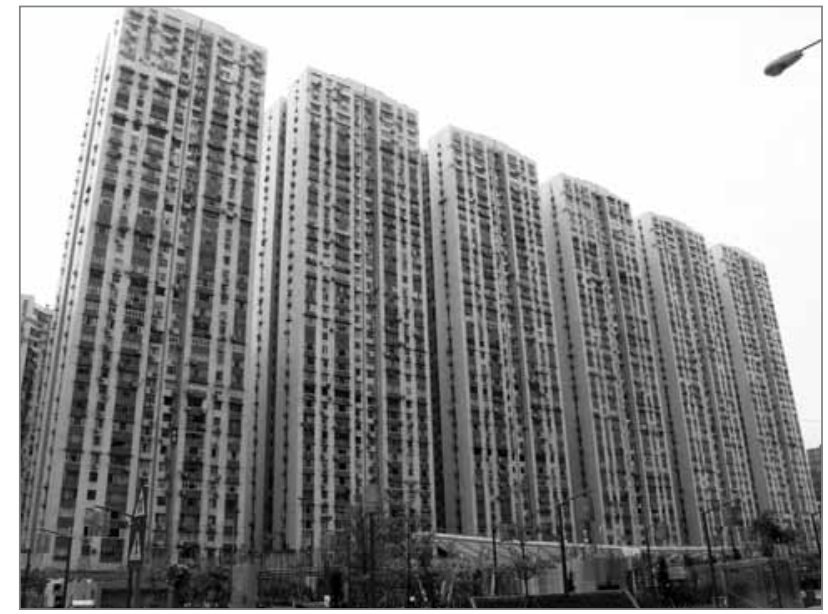

Figure 2: Nova Taipa Gardens (photo: Yung Yau).

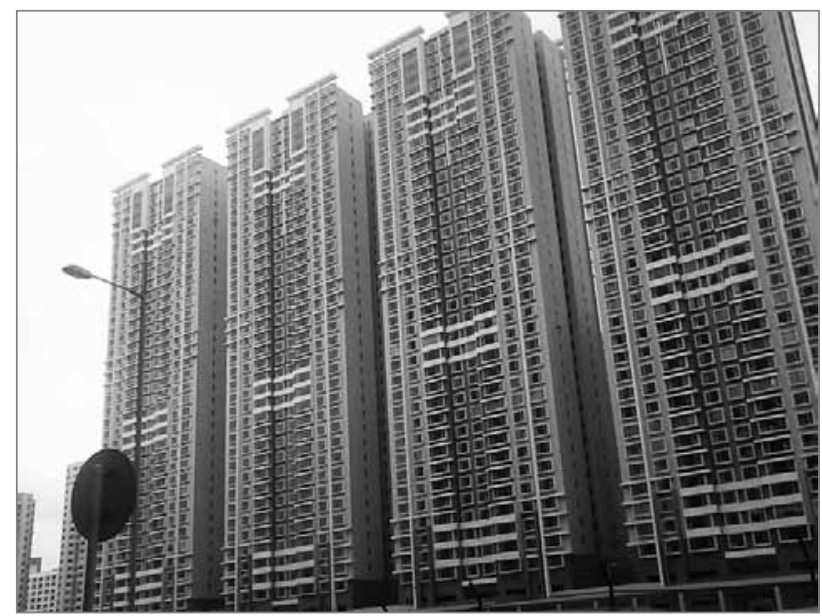

Figure 3: Nova City (photo: Yung Yau).

ous selected green construction attributes using a multi-criteria decision-making technique.

\subsection{Sampling and survey instrument}

In order to meet the research objective, potential homebuyers in the urban centre of Taipa (Portuguese: Baixa da Taipa), Macau were defined as the research population. Baixa da Taipa was chosen for two reasons. First, it is the major residential district in the city, accommodating most of the large-scale housing developments, such as Nova Taipa Gardens and Nova City. Figures 2 and 3 show these two developments. Second, residents in that district have the highest educational level compared with other parts of Macau. As of 2011, 27.5\% of the residents in Baixa da Taipa had at least a college degree (Statistics and Census Service, 2012). This characteristic is essential for the carrying out the research because it is preferable for the respondents to have some basic knowledge about green housing, and knowledge about green housing is believed to increase with education level.

Quota sampling was adopted. Despite the absence of randomness, quota sampling can be administered easily and with less 
cost. More importantly, a certain number of usable responses for meaningful analyses can be guaranteed using quota sampling. The final quota size was calculated in accordance with two principles. First, the total cost incurred in the design and implementation of the survey and data analysis was within the budget. Second, the sample was large enough to be representative for a preliminary study.

The 2011 census reported that there were 55,412 people living in the area (Statistics and Census Service, 2012). A quota size of 150 was deemed appropriate because it fulfilled both of these principles. A face-to-face survey was conducted, with the use of a present questionnaire, to collect the required information from the respondents. This approach was adopted to maximise number of valid questionnaires from the survey. Before the survey, the questionnaire was pretested and adjusted according to the testers' feedback. The final questionnaire had four sections. The first section contained a screening question on the respondents' intention to buy a residential property in the coming five years. The questionnaire would continue only when a respondent gave a positive response to this question. The second section concerned the socioeconomic details of the respondents. The third section contained questions on the respondents' WTP for a list of green housing attributes in their next home purchases on a five-point scale ( $5=$ "very willing" and $1=$ "not willing at all"). Finally, a set of questions allowed pairwise comparisons of the respondents' WTP for different green housing attributes.

\subsection{Green housing attributes under investigation}

Because there are countless types of green housing attributes on the market, it was impossible to investigate all of them in the research due to limited time and resources. With reference to the good practices and items credited in well-established green building assessment or rating systems such as the LEED, Building Research Establishment Environmental Assessment Method and Building Environmental Assessment Method Plus, six green housing attributes were chosen as the subjects of investigation. These attributes were:

1. use of timber from sustainable sources for construction;

2. use of prefabricated building elements for construction;

3. use of LED lighting in housing units;

4. installation of photovoltaic (PV) panels for generating energy for use in common areas;

5. use of water-saving showerheads in bathrooms in housing units; and

6. installation of a grey-water recycling system for use in common areas.

These six attributes were selected for their common applications in the housing sector. Otherwise, the respondents might have no prior experience or knowledge about the attributes,

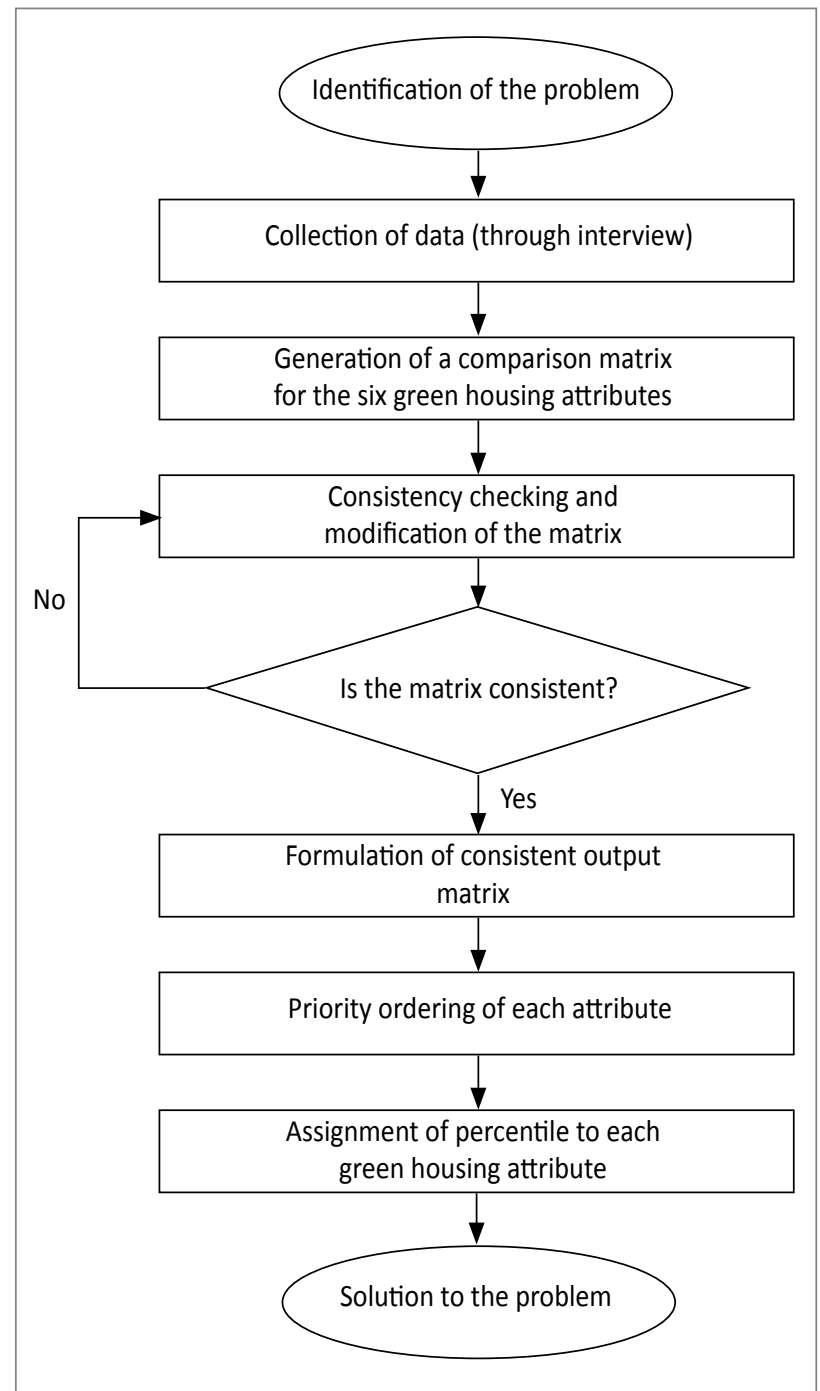

Figure 4: Work flow of the NSFDSS (adapted from Tam et al., 2002 and Yau, 2012).

Table 1: Example of an input matrix for pairwise comparison.

\begin{tabular}{lllllll}
\hline Attribute & \multicolumn{2}{l}{ Input Value } \\
\hline & $(1)$ & $(2)$ & $(3)$ & $(4)$ & $(5)$ & $(6)$ \\
\hline$(1)$ & 0.5 & 1 & 1 & 0.5 & 0 & 1 \\
\hline$(2)$ & & 0.5 & 1 & 0 & 0 & 1 \\
\hline$(3)$ & & & 0.5 & 0 & 0 & 0.5 \\
\hline$(4)$ & & & & 0.5 & 0 & 1 \\
\hline$(5)$ & & & & & 0.5 & 1 \\
\hline$(6)$ & & & & & & 0.5
\end{tabular}

and so their WTP from the survey would not be credible. Moreover, the six selected attributes had different natures and scopes of application. For example, Attributes 1 and 2 are related to the use of green materials or construction methods, whereas Attributes 3 and 4 deal with the energy use in a building (e.g., energy efficiency and use of renewable energy). The 
remaining two attributes are associated with water consumption and reuse. Furthermore, Attributes 3 and 5 are confined to private housing space, whereas common areas of buildings are focused on with Attributes 4 and 6. Attributes 1 and 2 involve both private and common areas of buildings. This great variety aims to facilitate the comparison of WTP for green housing attributes of different natures.

\subsection{Comparison of WTP}

In this research, WTP for the six selected green housing attributes was compared using a dual approach. First, the mean scores for each of the attributes were calculated and compared based on the findings from the third section of the questionnaire. Second, the respondents' WTP for different green housing attributes were compared using a non-structural fuzzy decision support system (NSFDSS). This technique has been widely adopted to determine factor weightings in multi-criteria decision-making (Yau \& Chan, 2008; Fung \& Yau, 2009; Yau, 2012), and it is applicable to the prioritisation of various green housing attributes with reference to the respondents' WTP. The workflow of the NSFDSS, as shown in Figure 4, was adapted from two studies (Tam et al., 2002 and Yau, 2012). In brief, each respondent was given 15 pairs of attributes (i.e., $6 \times(6-1), 2)$ because the total number of attributes was six. In each pairwise comparison, the respondent had to state which attribute he or she was more willing to pay for or state his or her indifference. A comparison matrix was then resulted for the respondent, and the internal consistency of the inputs could be checked. These exercises were aided with the input matrix in Table 1. The respondents could choose one out of the three output values $(0,0.5$ or 1$)$ for each pairwise comparison. For example, an output value of 1 is assigned when Attribute 1 (i.e. the attribute in the column) attracts a stronger WTP from the respondent than Attribute 2 (i.e. the attribute in the row). A value of 0 is used when the respondent's WTP for Attribute 1 is weaker than that for Attribute 5. A value of 0.5 is allotted when the WTP for Attributes 1 and 4 are at the same level.

With the completed input matrix, the internal consistency of a respondent's inputs could be checked. In this case, the number of housing attributes to be considered is six, and so the matrix of pairwise comparison is (Equation 1)

$$
\left.B\left[\begin{array}{llllll}
b_{11} & b_{12} & b_{13} & a_{14} & b_{15} & b_{16} \\
b_{21} & b_{22} & b_{23} & a_{24} & b_{25} & b_{26} \\
b_{31} & b_{32} & b_{33} & a_{34} & b_{35} & b_{36} \\
b_{41} & b_{42} & b_{43} & a_{44} & b_{45} & b_{46} \\
b_{51} & b_{52} & b_{53} & a_{54} & b_{55} & b_{56} \\
b_{61} & b_{62} & b_{63} & b_{64} & b_{65} & b_{66}
\end{array}\right]=\left(b_{m n}\right) \quad z a \quad \begin{array}{l} 
\\
b_{6}
\end{array}\right]=1,2,3,4,5,6
$$

where $b_{m n}$ is the logical indicator of pairwise comparison with housing attributes $m$ and $n$. The matrix of pairwise comparison, which is a square matrix, can be completed using the input matrix, although the input matrix comprises only the upper triangle. The lower triangle was obtained by subtracting the transposed upper triangle from one. Internal consistency was checked by identifying the case of intransitivity (e.g., $b_{12}>b_{13}$ but $b_{34}<b_{24}$ ). If intransitivity was spotted, the respondent would be asked to revise his or her input values.

Next, the green housing attributes were prioritised according to the results of pairwise comparisons. As illustrated in Table 2, the values in each row were summed up. A housing attribute with a larger sum means the respondent is more willing to pay a premium for it. In the example, the respondent has the strongest WTP for Attribute 5 and weakest WTP for Attributes 3 and 6. The attributes were then rearranged in descending order of the row sum. Based on the priority order, a percentile ${ }^{[1]}$ was assigned to each attribute. The attribute attracting the strongest WTP (Attribute 5 in the example) was assigned $100 \%$. The remaining attributes were compared to it one by one, and they were assigned a percentile not greater than $100 \%$. The general rule was that a higher percentile was given to an attribute with a higher priority. Each percentile was assigned a semantic score $s_{x}$ in the range of $[1,0.5]$, with 1 meaning "same level of WTP" and 0.5 meaning "not willing to pay for", as shown in Table 3. Afterwards, the semantic score was converted into a priority score $r_{x}$ in the range of $[1,0]$ by applying fuzzy set theory through the following equation (Equation 2; Tam et al., 2002):

$$
r_{x}=\frac{1-s_{x}}{s_{x}} \quad, \quad 0,5 \leq s_{x} \leq 1
$$

The priority score indicated the relative preference of each attribute. The aggregate priority score for a particular attribute was taken as the arithmetic mean of all the priority scores of individual respondents. For easy interpretation, the aggregate priority scores of the six housing attributes were rescaled so that the aggregate priority score of the attribute that attracted the strongest WTP by the respondents would be unity (or $100 \%)$. The advantage of using the NSFDSS was significant because direct prioritisation of the six attributes with reference to the WTP at the same time could result in unstable and inconsistent ranking due to cognitive incapacity of the respondents. Moreover, the NSFDSS, which is theoretically sound, allowed meaningful comparison of the WTP among the attributes. 
Table 2: An example of priority ordering.

\begin{tabular}{llllllll}
\hline Attribute & Input Value & & & & & Row Sum \\
\hline & $(1)$ & $(2)$ & $(3)$ & $(4)$ & $(5)$ & $(6)$ & \\
\hline$(1)$ & 0.5 & 1 & 1 & 0.5 & 0 & 1 & 4.0 \\
\hline$(2)$ & 0 & 0.5 & 1 & 0 & 0 & 1 & 2.5 \\
\hline$(3)$ & 0 & 0 & 0.5 & 0 & 0 & 0.5 & 1.0 \\
\hline$(4)$ & 0.5 & 1 & 1 & 0.5 & 0 & 1 & 4.0 \\
\hline$(5)$ & 1 & 1 & 1 & 1 & 0.5 & 1 & 5.5 \\
\hline$(6)$ & 0 & 0 & 0.5 & 0 & 0 & 0.5 & 1.0 \\
\hline
\end{tabular}

\section{Research findings, analyses and discussion}

\subsection{Findings from the survey and analyses}

Altogether, 150 valid questionnaires were completed between May and August 2013. Table 4 summarises the socio-demographic characteristics of the respondents. Given that the median household income and average household income in Macau were MOP\$23,700 and MOP\$29,853, respectively, in 2011, the distribution of the respondents among different income groups was quite even (Statistics and Census Service, 2012). On the other hand, the respondents tended to have higher educational attainment compared with the general level in the city. As shown in Table 5, among the six housing attributes, the use of water-saving shower heads attracted the strongest WTP from the respondents (mean score $=3.29$ ), followed by the use of LED lighting (mean score $=3.27$ ). The mean scores of these two attributes were not significantly different even at the $10 \%$ level. Installation of PV panels (mean score $=3.02$ ) and installation of a grey-water recycling system (mean score $=2.95)$ ranked third and fourth in terms of the WTP reported by the respondents. The mean scores of these two attributes were significantly lower than those for the use of water-saving shower heads and LED lighting (at the 10\% level at least). With mean scores of 2.67 and 2.77 , respectively, use of prefabricated construction elements and timber from sustainable sources received the weakest WTP from the respondents.

A similar set of results were obtained for the relative WTP of the six green housing attributes, presented in Figure 5. In the figure, the values shown in the parentheses are the aggregated priority scores of the green housing attributes after rescaling. The uses of LED lighting and water-saving shower heads ranked first and second, respectively, in terms of the aggregated priority scores. On the other hand, the use of prefabricated construction elements was regarded as the least attractive attribute. Its priority score was only $36.7 \%$ of that of the use of LED lighting. Installation of PV panels and grey-water recycling system and use of timber from sustainable sources took the middle positions in the league.
Table 3: Table for conversion between percentile, semantic score and priority score.

\begin{tabular}{lll}
\hline Percentile (\%) & Semantic Score, $s_{x}$ & Priority Score, $r_{x}$ \\
\hline 100 & 0.500 & 1.000 \\
\hline 95 & 0.525 & 0.905 \\
\hline 90 & 0.550 & 0.828 \\
\hline 85 & 0.575 & 0.739 \\
\hline 80 & 0.600 & 0.667 \\
\hline 75 & 0.625 & 0.600 \\
\hline 70 & 0.650 & 0.538 \\
\hline 65 & 0.675 & 0.491 \\
\hline 60 & 0.700 & 0.429 \\
\hline 55 & 0.725 & 0.379 \\
\hline 50 & 0.750 & 0.333 \\
\hline 45 & 0.775 & 0.290 \\
\hline 40 & 0.800 & 0.250 \\
\hline 35 & 0.825 & 0.212 \\
\hline 30 & 0.850 & 0.176 \\
\hline 25 & 0.875 & 0.143 \\
\hline 20 & 0.900 & 0.111 \\
\hline 15 & 0.925 & 0.081 \\
\hline 10 & 0.950 & 0.053 \\
\hline 5 & 0.975 & 0.026 \\
\hline
\end{tabular}

\subsection{Discussion}

The findings about the reported WTP (mean scores of the direct answers on a five-point scale) and relative WTP (priority scores generated with the NSFDSS) largely coincided. The Spearman's correlation coefficient between the two series was 0.89 , which was statistically significant at the $1 \%$ level. This high correlation helped validate the WTP self-reported by the respondents. From the research findings, it is clear that different levels of WTP were associated with green housing attributes with dissimilar natures. The respondents gave preferences to those attributes that could provide direct economic 
Table 4: Socio-demographic profiles of the respondents $(n=150)$

\begin{tabular}{|c|c|c|c|}
\hline Characteristic & & Frequency & Percentage \\
\hline \multirow{2}{*}{ Gender } & Male & 82 & $54.7 \%$ \\
\hline & Female & 68 & $45.3 \%$ \\
\hline \multirow{5}{*}{ Age } & $20-29$ years old & 7 & $4.7 \%$ \\
\hline & $30-39$ years old & 22 & $14.7 \%$ \\
\hline & $40-49$ years old & 56 & $37.3 \%$ \\
\hline & $50-59$ years old & 50 & $33.3 \%$ \\
\hline & 60 years old or above & 15 & $10.0 \%$ \\
\hline \multirow{4}{*}{ Educational attainment } & Primary education or below & 23 & $15.3 \%$ \\
\hline & Junior secondary education & 7 & $4.7 \%$ \\
\hline & Senior secondary education & 28 & $18.7 \%$ \\
\hline & Tertiary education or above & 92 & $61.3 \%$ \\
\hline \multirow{5}{*}{ Monthly household income } & MOP\$9,999 or below & 21 & $14.0 \%$ \\
\hline & MOP\$10,000-19,999 & 38 & $25.3 \%$ \\
\hline & MOP\$20,000-29,999 & 36 & $24.0 \%$ \\
\hline & MOP\$30,000-39,999 & 38 & $25.3 \%$ \\
\hline & MOP\$40,000 or above & 17 & $11.3 \%$ \\
\hline
\end{tabular}

Notes: 1) Percentages may not add up to $100 \%$ due to rounding; 2) MOP\$1 is approximately equivalent to USD 0.125 or EUR 0.091 as of 30 April 2014.

Table 5: Survey findings on reported WTP $(n=150)$

\begin{tabular}{lcc}
\hline Green housing attribute & \multicolumn{2}{c}{ Reported WTP } \\
\cline { 2 - 3 } & (5 = very willing; 1 = not willing at all) \\
\hline Use of water-saving shower heads & Mean & $\sigma$ \\
\hline Use of LED lighting & 3.29 & 1.25 \\
\hline Installation of PV panels & 3.27 & 1.22 \\
\hline Installation of a grey-water recycling system & 3.02 & 1.28 \\
\hline Use of timber from sustainable sources & 2.95 & 1.28 \\
\hline Use of prefabricated construction elements & 2.77 & 1.26 \\
\hline
\end{tabular}

benefits to them. For example, LED lighting and water-saving shower heads can reduce electricity and water consumption, helping respondents pay less for utilities (for LED lighting see for example Rankel, 2014).

On the other hand, although PV panels and a grey-water recycling system can also decrease electricity and water consumption, they were not so preferred by the respondents for two possible reasons. First, investments in these usually incur high initial costs. Homebuyers may expect longer payback periods for these investments. Second, on account of the research design, these two installations were assumed to be used in common areas only. In this sense, individual homebuyers might not perceive economic benefits that were significantly large enough to influence their home purchase decisions even if these installations could actually conserve energy and water in the end. Therefore, PV panels and grey-water recycling systems used in common areas attracted less WTP than LED lighting and water-saving shower heads used in private housing units. At the other extreme, although the use of prefabrication in construction can reduce waste and save resources, its economic benefits to homebuyers are not so direct or explicit. Moreover, prefabrication does nothing for occupants' health, and so there is no impact on health and productivity. Similar logic applies to the use of timber from sustainable sources. These are perhaps the reasons why fewer respondents were willing to pay more for these attributes.

The research findings do not deny the effects of moral or altruistic beliefs on people's WTP for green housing attributes. However, they suggest that the respondents' WTP for green housing attributes was largely motivated by economic incentives. The findings offer valuable insights for governments into the types of green construction attributes local people are will- 


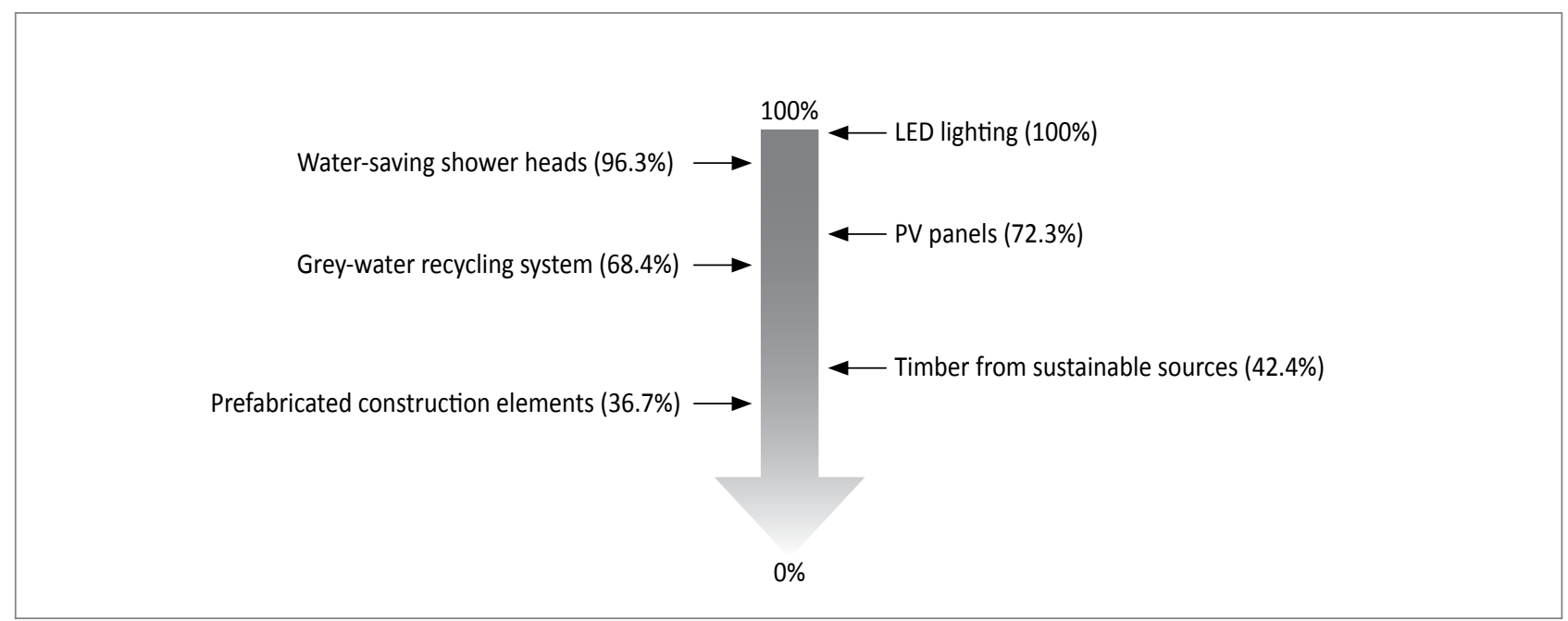

Figure 5: Relative WTP for the six green housing attributes (illustration: Yung Yau).

ing to pay extra for. In addition to their relatively low costs, installations such as LED lighting and water-saving shower heads attract strong WTP from housing consumers. Even if their costs are a bit higher than their non-eco-friendly counterparts, developers' additional costs can be more readily paid back or covered by the market. In this regard, governments should let market forces drive the supply of these green housing attributes, and developers should not be subsidised for providing them. Following this logic, installations of water-efficient fittings should not be included in the Green Mark Scheme in Singapore because construction proposals with high Green Marks are eligible for a bonus floor area, which is a kind of government subsidy.

In brief, governments should economise subsidies and allocate their limited resources to areas not valued by housing consumers. For example, as suggested by the empirical findings of the research, use of prefabricated construction elements and timber from sustainable sources are appealing to homebuyers' WTP. Therefore, in order to promote their use in new housing developments, governments should subsidise developers for using such construction methods or materials, if not making their use mandatory. In this sense, the initiative of some governments such as the Hong Kong government to offer developers bonus floor area for their uses of prefabricated facades in their new developments seems justifiable.

As a matter of fact, the WTP for a particular type of green housing attribute is socially constructed. A limited understanding of the benefits of an attribute can be a key inhibitor to realising housing consumers' WTP for it. From a policy point of view, governments should try their best to inform housing consumers or end-users of the true benefits and values of different green housing attributes. What is equally important is that information about homebuyers' WTP must be conveyed to other market players for the efficient functioning of the housing market. Therefore, there is a need to remove information barriers and improve communication and information-sharing among decision-makers such as consumers, investors and developers. Otherwise, erroneous perceptions about the high costs and low benefits of building green prevail, and higher environmental performance goals are often dismissed by the players in the residential construction sector. Moreover, due to limited resources, only six green housing attributes were investigated in this research. Further research should be carried out on the WTP for other green or eco-friendly housing attributes (e.g., green roofs and better thermal insulation).

\section{Conclusion}

The evidence base in environmental consumerism in the housing market is small but growing (CB Richard Ellis, 2009). A study was conducted to explore the WTP of 150 potential homebuyers in Macau for six different green housing attributes. The research findings suggested that the WTP for these attributes varied with the nature of the attribute. Driven by economic incentives, the respondents linked their strong WTP to installations or features that would offer them direct financial benefits. In light of increasingly tight public budgets, there is an urgent need to economise state subsidies for promoting green buildings. The research findings shed light on the shaping of public policy to achieve a sustainable built environment in a city.

The research described in this article investigated the economics of green construction from potential homebuyers' perspective. In fact, given that some conditions have been fulfilled, the command-and-control approach and subsidisation are not needed to promote certain types of green housing attributes even if consumers are unwilling to pay extra for them. For 
instance, the use of prefabrication and reusable formworks help developers fulfil their corporate social responsibilities. Such actions of corporate social responsibility can be rewarded by the market, for example, in the form of improved company reputation or goodwill, which facilitates brand differentiation in a crowded marketplace. In this case, developers are willing to use green technologies and materials for construction even if higher costs are incurred. In other words, materialising the values of corporate social responsibilities for developers or investors is another way to achieve the highest level in Figure 1.

Apart from attribute characteristics, there may be other determinants of homebuyers' WTP for green housing attributes. For example, WTP may be contingent on consumers' socioeconomic characteristics, such as gender, age, education level and income, as suggested by a large volume of literature (e.g., Diamantopoulos et al., 2003; Jensen et al., 2003; Zarnikau, 2003; Gossling et al., 2005). Moreover, environmental attitude has long been regarded as a determinant of consumer's WTP for green or eco-friendly products (Chyong et al., 2006; Hansla et al., 2008). Therefore, whether all these factors matter in determining the WTP for green housing attributes or not is worth studying in the future. By identifying who is willing (and who is unwilling) to pay extra for green housing attributes, governments can engage in more informed policy-making to promote green housing development.

\section{Yung Yau}

City University of Hong Kong, Department of Public Policy, Kowloon Tong, Kowloon, Hong Kong

E-mail:y.yau@cityu.edu.hk

\section{Shuk Man Chiu}

The Government of the Hong Kong Special Administrative Region,

Kowloon, Hong Kong

E-mail: chiusisters@hotmail.com

\section{Wai Kin Lau}

City University of Hong Kong, Department of Public Policy, Kowloon Tong, Kowloon, Hong Kong

E-mail:wklau39@cityu.edu.hk

\section{Notes}

[1] This kind of "percentile operation" is common for various types of fuzzy morphology and decision-making models.

\section{Acknowledgment}

The authors would like to express gratitude to volunteers from Macau University for their assistance in collecting data.

\section{References}

Australian Building Codes Board (2006) Proposal to amend the building code of Australia to increase the energy efficiency requirements for houses. Canberra.

Banfi, S., Farsi, M., Filippini, M. \& Jakob, M. (2008) Willingness to pay for energy-saving measures in residential buildings. Energy Economics, 30(2), pp. 503-516. DOI: 10.1016/j.eneco.2006.06.001

Bartlett, E. \& Howard, N. (2000) Informing the decision makers on the cost and value of green building. Building Research and Information, 28(5-6), pp. 315-324. DOI: 10.1080/096132100418474

Bhatti, M. (1996) Housing and environmental policy in the UK. Policy and Politics, 24(2), pp. 159-170. DOI: 10.1332/030557396782107052

Blend, J. \& van Ravenswaay, E. O. (1999) Measuring consumer demand for ecolabeled apples. American Journal of Agricultural Economics, 81(5), pp. 1072-1077. DOI: 10.2307/1244086

Borchers, A. M., Duke, J. M. \& Parsons, G. R. (2007) Does willingness to pay for green energy differ by source? Energy Policy, 35(6), pp. 33273334. DOl: 10.1016/j.enpol.2006.12.009

Boyle, K. J. (2003) Introduction to revealed preference methods. In Champ, P. A., Boyle, K. J. \& Brown, T. C. (eds.) A primer on nonmarket valuation, pp. 259-268. Dordrecht, Kluwer Academic. DOI: 10.1007/978-94-007-0826-6_8

Cajias, M. \& Piazolo, D. (2013) Green performs better: Energy efficiency and financial return on buildings. Journal of Corporate Real Estate, 15(1), pp. 53-72. DOI: 10.1108/JCRE-12-2012-0031

Casals, X. G. (2006) Analysis of building energy regulation and certification in Europe: Their role, limitations and differences. Energy and Buildings, 38(5), pp. 381-392. DOI: 10.1016/j.enbuild.2005.05.004

CB Richard Ellis (2009) Who pays for green? The economics of sustainable buildings. Los Angeles.

Chinese Academy of Social Sciences (2013) Reconstruction of China lowcarbon city evaluation and indicator system: A methodological guide for application. Beijing, Social Sciences Academic Press.

Chyong, H. T., Phang, G., Hasan, H. \& Buncha, M. R. (2006) Going green: A study of consumers' willingness to pay for green products in Kota Kinabalu. International Journal of Business and Society, 7(2), pp. 40-54.

Council for Sustainable Development (2009) Building design to foster a quality and sustainable built environment: Invitation for response document 2009. Hong Kong.

Diamantopoulos, A., Schlegelmilch, B. B., Sinkovics, R. R. \& Bohlen, G. M. (2003) Can sociodemographics still play a role in profiling green consumers? A review of the evidence and an empirical investigation. Journal of Business Research, 56(6), pp. 465-480. DOI: 10.1016/S0148-2963(01)00241-7

Ding, Y. C. (2006) Good to be green: Green building promotion policy in Taiwan. Taipei, Architecture and Building Research Institute, Ministry of the Interior.

Eichholtz, P., Kok, N. \& Quigley, J. (2009) Doing well by doing good? An analysis of the financial performance of green office buildings in the USA. London, The Royal Institution of Chartered Surveyors.

Eichholtz, P., Kok, N. \& Quigley, J. (2013) The economics of green building. The Review of Economics and Statistics, 95(1), pp. 50-63. DOI: 10.1162/REST_a_00291

Eichholtz, P., Kok, N. \& Yonder, E. (2012) Portfolio greenness and the financial performance of REITs. Journal of International Money and Finance, 31(7), pp. 1911-1929. DOI: 10.1016/j.jimonfin.2012.05.014 
Fuerst, F. \& McAllister, P. (2008a) Green noise or green value? Measuring the price effects of environmental certification in commercial buildings. Reading, School of Real Estate and Planning, University of Reading.

Fuerst, F. \& McAllister, P. (2008b) Pricing sustainability: an empirical investigation of the value impacts of green building certification. Paper presented at the ARES Annual Meeting 2008, 16-19 April, South Seas Island Resort, Captiva Island, FL, USA. Typescript.

Fuerst, F. \& McAllister, P. (2010) What is the effect of eco-labelling on office occupancy rates in the USA. London, The Royal Institution of Chartered Surveyors.

Fuerst, F. \& McAllister, P. (2011) Green noise or green value? Measuring the effects of environmental certification on office values. Real Estate Economics, 39(1), pp. 45-69. DOI: 10.1111/j.1540-6229.2010.00286.x

Fung, W. B. \& Yau, Y. (2009) Weightings of decision-making criteria for neighbourhood renewal: Perspectives of university students in Hong Kong. Journal of Urban Regeneration and Renewal, 2(3), pp. 238-258.

Gossling, S., Kunkel, T., Schumacher, K., Heck, N., Birkemeyer, J., Froese, J., et al. (2005) A target group-specific approach to 'green' power retailing: Students as consumers of renewable energy. Renewable and Sustainable Energy Reviews, (9)1, pp. 69-83. DOI: 10.1016/j.rser.2004.01.005

Hansla, A., Gamble, A., Juliusson, A. \& Gärling, T. (2008) Psychological determinants of attitude towards and willingness to pay for green electricity. Energy Policy, 36(2), pp. 768-774.

DOI: 10.1016/j.enpol.2007.10.027

Högberg, L. (2013) The impact of energy performance on single-family home selling prices in Sweden. Journal of European Real Estate Research, 6(3), pp. 242-261.

Hyland, M., Lyons, R. C. \& Lyons, S. (2013) The value of domestic building energy efficiency - Evidence from Ireland. Energy Economics, 40, pp. 943-952. DOI: 10.1016/j.eneco.2013.07.020

Jensen, K., Jakus, P. M., English, B. \& Menard, J. (2003) Market participation and willingness of pay for environmentally certified products. Forest Science, 49(4), pp. 632-641.

Joung, S. H., Park, S. W. \& Ko, Y. J. (2014) Willingness to pay for ecofriendly products: Case of cosmetics. Asia Marketing Journal, 15(4), pp. 33-49.

Karp, D. R. \& Gaulding, C. L. (1995) Motivational underpinnings of command-and-control, market-based and voluntarist environmental policies. Human Relations, 48(5), pp. 439-465.

Kats, G., Alevantis, L., Berman, A., Mills, E. \& Perlman, J. (2003) The costs and financial benefits of green buildings: A reports to California's Sustainable Building Task Force. Washington, DC, Capital E.

Krystallis, A. \& Chryssohoidis, G. (2005) Consumers' willingness to pay for organic food: Factors that affect it and variation per organic product type. British Food Journal, 107(5), pp. 320-343. DOI: $10.1108 / 00070700510596901$

Kwak, S., Yoo, S. \& Kwak, S. (2010) Valuing energy-saving measures in residential buildings: A choice experience Study. Energy Policy, 38(1), pp. 673-677. DOI: 10.1016/j.enpol.2009.09.022

Lorenz, D. \& Lützkendorf, T. (2008) Sustainability in property valuation: Theory and practice. Journal of Property Investment and Finance, 26(6), pp. 482-521. DOI: $10.1108 / 14635780810908361$

Maguire, P. \& Robinson, J. (2000) Building evaluation by prospective lessees. Paper presented at the CIB W70 International Symposium on Facilities Management and Asset Maintenance, 15-17 November, Brisbane, Australia. Typescript.

Maliene, V. \& Malys, N. (2009) High-quality housing - A key issue in delivering sustainable communities. Building and Environment, 44(2),

\section{pp. 426-430. DOI: 10.1016/j.buildenv.2008.04.004}

Matthiessen, L. F. \& Morris, P. (2004) Costing green: A comprehensive cost database and budgeting methodology. Los Angeles, CA, Davis Langdon.

May, P. J. (2004) Compliance motivations: Affirmative and negative bases. Law and Society Review, 38(1), pp. 41-68.

DOI: 10.1111/j.0023-9216.2004.03801002.x

Miller, N., Spivey, J. \& Florance, A. (2008) Does green pay off? Journal of Real Estate Portfolio Management, 14(4), pp. 385-399.

Millimet, D. L., Roy, S. \& Sengupta, A. (2009) Environmental regulations and economic activity: Influence on market structure. Annual Review of Resource Economics, 1, pp. 99-118.

DOI: 10.1146/annurev.resource.050708.144100

Ming Pao (2009) The government is considering making installation of eco-friendly devices in new buildings mandatory. 21 Nov. 2009, p. P2.

Moran, A. (1995) Tools of environmental policy: market instruments versus command-and-control. In: Eckersley, R. (ed.) Markets, the state and the environment: Towards integration, pp. 73-85. South Melbourne, Macmillan Education Australia.

Morri, G. \& Soffietti, F. (2013) Greenbuilding sustainability and market premiums in Italy. Journal of European Real Estate Research, 6(3), pp. 303-332.

Rankel, S. (2013): Future lighting and the appearance of cities at night: A case study. Urbani izziv, 25(1), str. 126-141. DOI: 10.5379/urbani-izziv-en-2014-25-01-004

Robinson, J. (2005) Property valuation and analysis applied to environmentally sustainable development. Paper presented at the 11th Pacific Rim Estate Society Conference, 23-27 January, Melbourne, Australia. Typescript.

Roe, B., Teisl, M. F., Levy, A. \& Russell, M. (2001) US consumers' willingness to pay for green electricity. Energy Policy, 29(11), pp. 917-925. DOI: 10.1016/S0301-4215(01)00006-4

Saphores, J.-D. M., Nixon, H., Ogunseitan, O. A. \& Shapiro, A. A. (2007) California households' willingness to pay for 'green' electronics. Journal of Environmental Planning and Management, 50(1), pp. 113-133. DOI: 10.1080/09640560601048549

South China Morning Post (2009) Don't reward developers, It's their duty to provide green features. 14 Dec. 2009, p. EDT10.

South China Morning Post (2010) Was green policy really meant to work like this? 31 Dec. 2010, p. EDT10.

Statistics and Census Service (2012) Results of 2011 population census. Macau, Documentation and Information Centre.

Suzuki, M., Oka, T. \& Okada, K. (1995) The estimation of energy consumption and $\mathrm{CO}_{2}$ emission due to housing construction in Japan. Energy and Buildings, 22(2), pp. 165-169. DOI: 10.1016/0378-7788(95)00914-J

Swan, L. G. \& Ugursal, V. I. (2009). Modeling of end-use energy consumption in the residential sector: A review of modeling techniques. Renewable and Sustainable Energy Reviews, 13(8), pp. 1819-1836. DOI: 10.1016/j.rser.2008.09.033

Tam, C. M., Tong, T. K. L., Chiu, G. C. \& Fung, I. W. H. (2002) Non-structural fuzzy decision support system for evaluation of construction safety management system. International Journal of Project Management, 20(4), pp. 303-313. DOI: 10.1016/\$0263-7863(00)00055-7

Viosky, R. P., Ozanne, L. K. \& Fontenot, R. J. (1999) A conceptual model of US consumer willingness-to-pay for environmentally certified wood products. Journal of Consumer Marketing, 16(2), pp. 122-140. DOI: $10.1108 / 07363769910260498$ 
Yau, Y. (2012) Multicriteria decision making for homeowners' participation in building maintenance. Journal of Urban Planning and Development, 138(2), pp. 110-120. DOI: 10.1061/(ASCE)UP.1943-5444.0000108

Yau, Y. \& Chan, H. L. (2008) To rehabilitate or redevelop? A study of the decision criteria for urban regeneration projects. Journal of Place Management and Development, 1(3), pp. 272-291.

DOI: $10.1108 / 17538330810911262$

Zarnikau, J. (2003) Consumer demand for "green power" and energy efficiency. Energy Policy, 31(15), pp. 1661-1672.

DOI: 10.1016/S0301-4215(02)00232-X 